\title{
Using Best Practices In Online Discussion And Assessment To Enhance Collaborative Learning
}

Debra L. Fleming, Ursuline College, USA

\begin{abstract}
The primary purpose of this exploratory study is to provide insight on how to use online discussions to foster collaborative learning and how to design assessment processes to evaluate the effectiveness of those discussions. This study focuses on the pedagogical role of discussion, effective practices in discussion, guidelines for creating discussions to enhance learning, and the use of rubrics for assessment and evaluation. This study also provides an overview of the pedagogy of online assessment with an emphasis on mastery learning instructional methods. Effective practices in the use of online assessment and guidelines for aligning learning objectives with the most appropriate assessment tool are also emphasized. This study concludes that using best practices in online discussion and assessment can enhance collaborative learning which results in students having a deeper understanding of course content because of more time on task, increased motivation, more engagement, improved teamwork and interpersonal skills, enhanced critical thinking abilities, improved self-esteem and increased ownership of their own learning.
\end{abstract}

Keywords: Technology, Instructional Methods, Online Discussions, Assessment, Rubrics, Collaborative Learning, Best Practices, and Business Courses

\section{THE PEDAGOGICAL ROLE OF DISCUSSION}

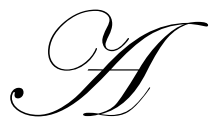

review of the literature indicates that that "interaction and sharing" is the heart and soul of teaching and learning processes (Harasim, Hiltz, Teles and Turoff, 1995). This is the contribution that questioning and discussion bring to the learning process. Although most faculty use questions of some kind in their courses they teach, some research studies indicate college professors often do not use questions effectively (Weimer, 1989). For example, two of the key problems cited in the literature are that faculty do not spend any significant amount of time asking questions and that the kinds of questions asked are simple, recall questions that don't require students to think (Weimer, 1989). This means that in some cases the use of questioning and discussion activity has not yet been tapped for its full potential.

Other research studies stress that it is not so much the concept or tool that improves teaching and learning but how the professor integrates the tool into the curriculum and into the educational setting (Funaro, 1999). For example, an important step in integrating technology to enhance discussion activity is to start the process by identifying an explicit definition of the pedagogical role for which that technology will be used. The pedagogical shift here is in emphasizing learning which either is part of an activity (activity theory) or is situated in an authentic environment (situated learning), and discussion is an important part of the strategy. Advocates of this shift promote the design of learning environments that are more interactive, project-oriented and learner-centered which take into account the varieties of students' learning styles (Berge, 1997). In comparison with the typical use of low-level questions identified by some researchers, others argue that carefully planned discussions elicit higher levels of critical, reflective thinking and creative problem-solving, including synthesis, application, and evaluation. There is also evidence that information learned through active discussion is generally retained better than material learned through lecture (Ewens, 1989). 
If these research conclusions are right, then why isn't discussion being used more and used more effectively? There are at least two factors that work against good discussion. One is that college faculty members often have not learned how to plan for discussion and the other is that discussion is not an efficient way of arriving at conclusions. For example, working through a discussion to come to some meaningful closure requires a lot of time and thought. If a faculty member is concerned about having enough time to cover a certain amount of material during a class period, then he or she is not going to devote substantial parts of that time for discussion. Even if an entire class period is devoted to discussion, there still might not be enough time for adequate discussion. Some professors have made attempts to address these concerns in two ways: (1) by moving rote lecture material out of the classroom, more time is available for such learning activities as discussion and (2) by using a course management system (CMS), other discussion areas are provided for the class. By enhancing a face-to-face class with a CMS, there are at least three different settings in which discussion can occur, such as in-class, synchronous online (chat rooms), or asynchronous online (bulletin boards or threaded discussions). The strategies for in-class discussion are adaptable to facilitation of online discussion, as well, so this study begins by examining effective practices in discussion and then deals with the special characteristics of online discussion.

\section{EFFECTIVE PRACTICES FOR DISCUSSION ACTIVITIES}

There is widespread agreement that effective discussion requires careful preparation on the part of the professor. Some researchers contend that effective discussion based activities require much more preparation than effective lecture based activities (Cashin and McKnight, 1989). Planning for classroom discussion requires in-depth knowledge of the purpose for asking the questions, such as addressing the question: what is the end to be achieved and how does it fit within developing or assessing student understanding of the topic under discussion?

Although preparation is necessary, many discussion strategies are relatively easy to implement and clear guidelines for their use in the classroom are readily available from the literature. For example, many discussion activities involve pairing up students for a few minutes of focused discussion rather than throwing a question out to the whole class and waiting for someone to answer. For example, one exercise is to ask students to work with one other student and decide together what they think is the primary value of the particular text for the day, and how their consideration of it meshes with course goals, sometimes referred to as a goal and value based technique (Frederick, 1989). After five minutes of discussion, the pairs report on their reactions. Other research studies present procedures for a number of different cooperative strategies. They include "turn to your neighbor summaries" in which students turn to a classmate and formulate answers to questions following a set of specified steps or read and explain pairs" in which the two students check one another on the accuracy of their summaries of assigned readings (Johnson, Johnson and Smith, 1998).

This type of shared learning or collaborative activity gives students an opportunity to engage in discussion, take responsibility for their own learning, and thus become critical thinkers (Totten, Sills, Digby, \& Russ, 1991). Some research studies suggest that for effective collaborative learning, there must be group goals and individual accountability (Slavin, 1989).When the group's task is to ensure that each group member has learned something, it is in the interest of each group member to spend time explaining concepts to members of the group. For example, a good discussion starter activity is to assign pairs of students to research a question or problem and report their results to the entire group. A further step is to ask teams to evaluate each other's work. Alternatively a team can be composed of three individuals, one of whom is charged with proposing an initial answer, the second provides a alternative answer, and the third provides a critique or synthesis of the first two responses (Slavin, 1989).

\section{EXAMPLE GUIDELINES FOR PREPARING AND FACILITATING DISCUSSION BASED ACTIVITIES}

Using appropriate guidelines for the preparation for discussion are as important as the previous listed suggestions for using collaborative learning strategies to enhance the effectiveness of discussion activities. For example, some typical guidelines for preparation are:

- $\quad$ Know what the goal is for the discussion; what are you trying to achieve by having the students engage in discussion? 
- $\quad$ Plan activities that have specific objectives in order to generate purposeful responses (Reiss, n.d.).

- $\quad$ Make sure students have prepared for the discussion by reading all the assigned readings first. The discussions should be literature-based (Lai, 1998).

- $\quad$ Identify content and concepts you want students to explore (Reiss, n.d.).

- $\quad$ Plan the discussions so that they will complement what happens in the rest of the course so that they are not tangential to the course (Sherry, 1998).

- $\quad$ Focus discussion on crucial points (Sherry, 1998).

- $\quad$ Develop questions or directions that will lead students to think about the topics in a way that generates and demonstrates understanding (Reiss, n.d.).

These guidelines deal with the faculty member's role in guiding the discussion:

- Serve as facilitator or guide on the side, not a sage on the stage and assume the role as a resource provider, rather than an expert dispensing knowledge to the student (Berge, 1997).

- $\quad$ Step back and let the students discuss without saying too much yourself (Cashin \& McKnight, 1989); a professor who answers everything will decrease the opportunities for student participation, and the discussion will become teacher centered rather than student centered (Harasim, Hiltz, Teles and Turoff, 1995).

- $\quad$ Create a friendly, safe and supportive environment for learning (Sherry, 1998; Harasim, Hiltz, Teles and Turoff, 1995); Whether instruction takes place in a conventional face-to-face class or a Web-based electronic forum, promoting a comfortable, safe environment for communication is essential to encourage students to participate (Cummings, 1998).

- $\quad$ Create high expectations of participation (Cashin \& McKnight, 1989).

- $\quad$ Invite responses and encourage interaction (Harasim, Hiltz, Teles and Turoff, 1995).

- $\quad$ Encourage and recognize students' contributions (Cashin \& McKnight, 1989).

- $\quad$ Allow for silence; students need to be given time to think (Cashin \& McKnight, 1989); a professor should be patient in waiting for student responses and not rush to fill the silence (Harasim, Hiltz, Teles and Turoff, 1995).

\section{BENEFITS OF USING ONLINE DISCUSSION BASED ACTIVITIES}

Online discussion can either take place when students are logged in at the same time and sharing messages back and forth in real time (synchronous) or at the student's convenience regardless of whether others are online at the time or not (asynchronous). Course Management Systems provide chat rooms for synchronous discussion. Asynchronous discussion is done through a bulletin board or threaded discussion section. Although chat rooms are important for true distance education, where students are not physically proximate, faculty who are using a CMS to enhance a face-to-face class find it less useful. Therefore, the discussion of benefits for online discussion will focus more on asynchronous discussion within a CMS bulletin board.

Research has consistently found that students who gain most from cooperative work are those who give and receive elaborated explanations (Webb, 1985). Other research studies have found substantial evidence of enhanced collaboration in the online setting. Approximately equal proportions of the behaviors of planning, contributing, and seeking input occurred in the online setting, with fewer occurrences of reflection and only a few comments classified as "social" (Curtis and Lawson, 2001). Another example of research that supports enhanced participation and collaboration is the report on a study at Athabasca University which suggests that online students experienced greater cognitive and explanatory learning as a result of greater participation in course communications where students exchanged between 80 and 100 messages, which is far richer than the traditional classroom setting (Paskey, 2001). This seems to imply that online discussions generate more messages and more involvement in learning.

The primary benefits of online discussion are: situated learning, increased time for discussion, total student participation, a voice to silent students, thoughtful and articulate responses; peer learning support, more time on task, a recorded transcript, and a forum for prompt feedback. Since learning occurs naturally within a social setting, online discussion based activities help students develop camaraderie within a discussion group. This means the 
discussion area becomes a social environment that can help motivate the learner and create a forum within which ideas can be tested and applied (Chism, 1998,). Thus, if technology is integrated effectively it can provide an electronic learning medium that fosters the kind of creativity and communication needed to stimulate engagement. The major premise of engagement theory is that students must be engaged in their course work in order for effective learning to occur. It is suggested that activities that involve discussion increases engagement which results in learning that is creative and meaningful (Shneiderman, 1994). There is also evidence that higher-level thinking occurs in online discussions (Garrison, Anderson and Archer, 2001; Curtis and Lawson, 2001; Paskey, 2001; Newman, Webb and Cochrane, 1991; and Shapley, 2000)). While higher-order thinking may (or may not) occur in the classroom, the evidence does appear to support earlier studies that students involved in threaded discussions are exhibiting higher-order thinking, especially by contributing comments that are exploratory, integrative, or resolution (Garrison, Anderson and Archer, 1994). Integration and resolution especially require time for reflection which may be more likely to occur in the extended time period of the threaded discussion.

Another benefit of using online discussions is that often the class ends before a discussion has reached closure, whereas, the asynchronous nature of the web-based discussion board avoids this circumstance. This means that a class discussion can go on indefinitely, or as long as two or more individuals are willing to devote the time to continuing a dialogue (Cummings, 1998,). Since an important goal is to move students from passive to active learners, full participation is essential. Unless a professor uses some of the small group discussion techniques described earlier, it is difficult to get everyone to participate in classroom discussion. Interestingly, the quiet student cannot hide in an electronic classroom, because being present in class is demonstrated by participating in the discussion (Cummings (1998). It is important to note that participation is easily monitored in computer conferencing and thus creates pressure for students to participate because it is more difficult to hide behind the medium because others will notice who has and who has not yet contributed to the discussion (Lai, 1998).

Interestingly, learning by doing and active learning are important principles that have emerged within the constructivist theory of learning (Bredo, 132). Therefore, the strategy of active participation in online discussion may be seen as a practice of this viewpoint. For some learners, active participation and engagement in online discussions throughout or during some parts of the online course may be influential in their learning. For others, active participation may be difficult or unwanted due to different reasons. For some students, discussing course topics online may be a very different experience than discussions in a face-to-face environment. Lurking or silence in formal online course discussions may be treated as an unwanted behavior because some professors view lurkers or silent participants as readers and beneficiaries of others' discussions, who do not share their own ideas (Salmon 2000). Kollock and Smith (1996) describe lurkers or silent participants as free-riders and non-contributing, resourcetaking members. Only a few online educators acknowledge that lurkers or silent participants are learning. These studies suggest that for these learners most learning actually occurs' in unseen dimensions of online learning, and that low visible participation does not imply less engagement in learning, but rather it is possible that silent learners are more engaged (Beaudoin, 2002). For example, Nonnecke_and Preece (2000) found "lurking" as not a passive but active involvement in reading and applying strategies to determine what to read, delete or save. Their studies also found that lurkers or silent participants can also feel a sense of community, when the dialogue engenders a safe environment and/or a sense of trust. The issue of safety is not only central to participation in discussions, but according to Maslow (1972) it is central to all learning. In an open online discussion list silent learners may feel uncomfortable in putting their opinions out in the open, or they may feel unconfident in challenging others' views. However, they may continue to maintain their safe learning zone by watching, drawing from an online discussion, and feeling free to choose the silent course of learning. Therefore, for online discussion related learning experiences to enable constructivist learning there needs to be an acknowledgement that some individuals may be learning informally and silently, not visible to others and professors need to enable informal and trustworthy learning spaces, where learners feel confident and supported in working on their own and with each other. For example, one strategy to address this issue would be to create private, small, group based discussion activities to provide individuals an opportunity to develop confidence and self-esteem in responding to a small number of students, prior to participating in a full class based discussion where all class members view their responses.

On the other hand, even though some students thrive in the give and take of a traditional face-to-face in class discussion, other students are not comfortable talking in class. They may be shy or come from cultures where 
answers and responses are considered and carefully framed before presentation (Berge, 1997). They are often thoughtful students, who need time to carefully craft what they want to say before they submit their responses for their classmates to review. During in-class discussion, the other students never get the benefit of the insights these students can provide. When discussions are drawn out over several days, these students blossom and join in the conversation. This relates to the next benefit, as well.

As the discussion becomes separated from time, the discussion tends to become the product of more deliberate reflection (Cummings, 1998). The students can take time to reflect and consider their response (Berge, 1997). The benefits of the writing process also come into play. As students prepare their responses they go through multiple drafts, sharpening their thinking and accumulating references with which to substantiate their arguments and positions (Berge, 1997). Some professors contend that a content analysis of class postings shows that students' responses are generally well thought out and lengthy (as compared to messages posted to newsgroups) and discussions were well elaborated and had depth (Lai's, 1998). This also applies to the professors, who can respond to students more thoughtfully than they may be able to "on the fly" in class (Funaro, 1999). It is important to note that different students with different strengths respond differently to the online setting. The student who learns or processes information by talking and who enjoys the give-and-take of discussion may feel disadvantaged in the online setting; the student who requires reflection to learn or construct an answer may be advantaged. Therefore, offering a mix of ways to be involved in discussion may well improve the likelihood that most students find an avenue for contributing that satisfies their learning needs. However, time for reflection is key to the learning of many students, and a few seconds in class may not be sufficient time to reflect and think about a course topic; thus, topics that require additional reflection would probably work best in the threaded discussion setting.

Another benefit on using online discussion based activity is that the process supports peer learning. For example, online discussion provides students with a space of their own where they can learn from each other. They can share their thinking with each other and comment on each other's ideas. Students appreciate having a window into the thinking processes of their peers. The asynchronous format also allows students to work through difficult texts and concepts more slowly and to help each other understand the material (Funaro, 1999).

In order for students to become engaged with the course's content, they must spend time working with and thinking about that content. Participation in discussion outside of class increases their involvement with the material. This type of discussion activity results in an additional benefit of increasing the "time on task" in which students are engaged in learning the material. Increasing time on task is noted as one of the most effective teaching strategies that a professor can use to enhance learning processes (Chickering and Ehrman, 1996).

The fact that the discussion is recorded provides a number of advantages. Students are held accountable for their participation (Sherry, 1998). The comments are available for review later as students prepare for assessment (Cummings, 1998). The professor can review the conversations and from them monitor each student's level of understanding of the material, catch common misconceptions, and gauge student interest in particular topics (Funaro, 1999). Other research studies make a similar point stressing that online group learning is an opportunity to see what students have learned and how they understand and apply the concepts. The presentation of ideas online enables the professor to see how the material is being intellectually interpreted and integrated by each student (Harasim, Hiltz, Teles and Turoff, 1995).

The threaded arrangement of messages in the bulletin board or threaded discussion section allows students to quickly check on any comments that have come from a message they have posted. This allows the students to benefit from feedback from their fellow students and the professor (Sherry, 1998). The discussion area provides a place where students can post their work-in-progress and a place where others can provide critique and feedback to help students refine their final product which supports peer learning (Sherry, 1998,).

Unfortunately, the impact of these advantages, while providing benefits to the student, also increases the time pressures on them. Some research reports that students complain about the increased work necessary to keep up with the current topic so they can actively participate thoughtfully. Some students complain of information overload, increased responsibility regarding online participation, and difficulty in following concurrent discussion threads 
(Sherry, 1998). Other research studies report similar experiences with an online course, where students were overwhelmed by the volume of e-mail which caused them to fall behind in reading and responding (Hara and Kling, 1999). It is also important to note there are similar pressures upon the professor. Some professors would concur that it takes less time to stand in front of a class and provide feedback on graded assignments than it takes to write well constructed paragraphs for individual feedback on the Web. However, despite the cost to the professor in terms of time, the conferencing assets of the web as a tool for promoting interaction and engagement among students provide a wealth of learning opportunities (Cummings, 1998).

\section{EXAMPLES OF EFFECTIVE PRACTICES IN ONLINE DISCUSSION}

As previously indicated there are numerous advantages of using online discussion based activities, especially when best practices are incorporated into the process. It is important to note that the following best practices for use in online discussions can also be applied to in class discussions, such as establishing clear expectations, determining groupings, creating grading criteria, facilitating guidelines and developing assessment tools.

It is important that expectations and guidelines for participation be clearly established at the beginning of the course.

The following list includes some suggestions for what should be communicated to the students:

- $\quad$ Require participation, even if not graded, participation should receive credit, and penalties should accrue for lack of participation. Likewise, rewards should accrue for active engagement in the discussions (Reiss, n.d.).

- $\quad$ Determine how many times a week students should participate. If participation is any less frequent that twice a week, the discussion may lag and participants may become frustrated with the delay in receiving feedback and reactions from peers (Harasim, Hiltz, Teles and Turoff, 1995).

- $\quad$ Deadlines should be set and a weekly pattern helpful. For example, you might establish a day on which initial postings need to be made and another day by which responses to the initial postings are to be completed.

- $\quad$ Limit the length of the postings, unless you are using them as a way of delivering reports and note that that single-page posting may be the optimal size. Reports could be handled as attachments. (Lai, 1998).

- $\quad$ Reiss (n.d.) suggests the following guidelines:

○ Length of message (75-150 words, for example)

- Level of formality (informal but not colloquial is a typical level-perhaps with a reminder that this space is a class not a cocktail party and that readability and clarity of meaning are the goals.)

- Time expectations (30 minutes maximum for each message, for example)

- Criteria for an acceptable response (for example, must include 1 example from the textbook and another from a journal article) along with any grading criteria, but consider using most of these messages as credited ungraded writing for discovery and learning

- Resources you expect students to consult as they develop their responses (if the resources are online, provide active hyperlinks). Invite students to contribute additional resources (and give them credit for doing so).

- Naming conventions (topic or subject lines to help you and students manage the messages-for example, include Message 1, Message 2, etc. in the name or have them add to the subject or topic line the name of the person they are replying to "Reply to Vince S. and Bob B. from Steve P.)

Funoma (1999) provides an example of how the professor can assist the student in preparing for online discussion by reproducing a handout prepared by a professor for an Introduction to Humanities class at Stanford University.

Preparing for Online Discussion - How do I post successfully? How do I get my friends to read my posts? 
- $\quad$ think of the assignment in terms of a dialogue not a writing exercise. You want to engage yourself in a discussion about the texts and issues of the course

- $\quad$ this means: elaborate one single idea and keep your message to one paragraph (150-200 words). Texts longer than 150-200 words are harder to follow on screen. Of course, better-formulated and clear posts attract more attention

- $\quad$ before you post: think about the assignment first and take (mental notes) before you read other responses think of a thesis and how you can support your thesis

- $\quad$ then read other posts

- $\quad$ respond to one that contradicts, or supports your own thoughts; one that is lacking evidence or seems to fall short on an aspect that is important to you

- $\quad$ in your response, you can also turn your own thoughts into questions, offer your argument (remember, an opinion is not an argument); play the devil's advocate; ask challenging questions

- $\quad$ avoid hermetic responses that offer only right and wrong perspectives and ignore other possible answers

- $\quad$ if you are the first to post: post with a careful analysis and strong (bold) argument (thesis) and open-ended questions that invite dialogue

- $\quad$ it helps for the readers of your post, if you include a specific quotation from the message you respond to (xx said:""); this way we know who you are referring too

- $\quad$ choose your title carefully (titles, such as "1. Assignment," are far less compelling than content related titles)

- $\quad$ once you have posted, check back if anybody has responded to you and get the dialogue going

Not only is it important to establish clear expectations for the discussion activities, but also of equal importance is to determine groupings for how students are to participate in the discussion activity. For example, for large lecture classes, break up the class into discussion groups of five to ten people. Have some threads that are for the whole class, but reserve most for within the groups. In a class of 60 students where each student is to post and respond during a week, there will be at least 120 messages to read. Students will be overwhelmed quickly and will just give up trying to keep up with all of the postings. As more and more classes begin implementing online discussion, this will become an increasing problem for students.

Some research studies indicated that students are capable of performing at higher intellectual levels when asked to work in collaborative situations than when asked to work individually (Vygotsky, 1978). Group diversity in terms of knowledge and experience contributes positively to the learning process. Others contend that cooperative learning methods improve problem-solving abilities because the students are confronted with different interpretations of the given situation and that the peer support system makes it possible for the learner to internalize both external knowledge while improving both critical thinking and interpersonal skills (Bruner, 1985). Each member of the group has opportunities to contribute in small groups. Students are apt to take more ownership of their material and to think critically about related issues when they work as a team. Because there are more exchanges among students in small groups, students receive more personal feedback about their ideas and responses. This feedback is often not possible in large-group instruction, in which one or two students exchange ideas and the rest of the class listens. Horn (1994) and Hirumi and Bermudez (1996) are among those who find that, with proper instructional design, online discussion activities can be more interactive than traditional ones, providing more personal and timely feedback to meet students' needs than is possible in large, face-to-face courses.

Groups can be formed by the professor or students or both. If you are having students form the groups, an in-class signup with set number of slots is still the easiest way to do this; students forming groups or picking topics and then e-mailing the professor gets to be an administrative nightmare and leads to hard feelings when students don't get the pairings or topics they request. Trying to do it through e-mail or online discussion slows down the process, as well, delaying the start of the groups' work. While students like to break up into groups of friends, some research in this area suggests that this approach is the least effective grouping technique. A more effective approach is to use random or professor selection with the goal to produce heterogeneous groups in which there is more opportunity to learn from others who have different perspectives (Johnson, Johnson and Smith, 1998). The size and composition of the groups may vary through the class, though too many group memberships get confusing. Students 
forget which team is working on what. Generally, don't have more than two different project groupings through the term (not counting small group or pairing activities during a class session).

\section{SUMMARY GUIDELINES FOR FACILITATING ONLINE DISCUSSIONS}

- $\quad$ Do not lecture because an elaborate, long, text-based presentation may produce silence. If an e-lecture is used, keep it short and focused, and include open-ended remarks and interesting questions to stimulate discussion. (Harasim, Hiltz, Teles and Turoff, 1995)

- $\quad$ Space out discussions to avoid having the students or the grader overwhelmed by the number of postings. (Funoma, 1999)

- $\quad$ Establish realistic expectations for how many postings you will read and respond to each week and make these expectations clear to the students. (Funoma, 1999)

- $\quad$ Model responsiveness. (Harasim, Hiltz, Teles and Turoff, 1995)

- $\quad$ Provide timely feedback. (Hara \& Kling, 1999)

- $\quad$ Participate as appropriate, such as either a peer or a mentor and provide feedback to praise what is best in their messages, as well as to provide additional information on the topic. (Reiss, n.d.)

- $\quad$ Encourage students to compliment or respond to one another. One means to do this is to redirect a question from one student to another, who is specified by name. For example, 'John, your question is a very important one. Connie, Carol and Don, what are your thoughts on this issue?' In either the group discussion or private messages, ask individuals to respond to particular topics or items, based on knowledge of their interests and experiences. (Harasim, Hiltz, Teles and Turoff, 1995)

- $\quad$ Positively reinforce discussion contributions, and negatively reinforce silence. (Harasim, Hiltz, Teles and Turoff, 1995)

- $\quad$ Close the discussions with a synthesis the topic which may be written either by the professor or by students. (Harasim, Hiltz, Teles and Turoff, 1995 )

- $\quad$ Regular reading of the discussion and integration of ideas from the discussion into class discussions shows students that the professor takes the discussion seriously. (Funoma, 1999)

- $\quad$ Cashin \& McKnight (1989) provide useful recommendations on how to facilitate a discussion and ask questions that encourage interaction among students. Even though their ideas refer to in-class discussions, most of the principles apply to the online environment as well, such as "request examples or illustrations" and "use divergent questions."

\section{THE PEDAGOGY OF ASSESSMENT AND ONLINE ASSESSMENT TOOLS}

Not only is it important to analyze the pedagogy of discussion but also it is important to analyze the pedagogy of assessment. Student assessment, in general, is a powerful educational tool that can serve both teaching and learning. When used in teaching, assessments can determine if students are learning what they need to learn. Professors can gauge how well they are doing in presentation of the course material. Or stated a different way, professors know if the students are "getting it". As a result of such investigations a professor may choose to modify subsequent learning activities, recommend strategies to minimize difficulties, or provide feedback that allows the student to self correct or proceed to advanced studies (Dochy \& McDowell, 1997).

Throughout the learning process, assessment motivates and helps students structure learning and study skills. A well-constructed assessment can provide students with insight as to what they need to focus on in order to master the material. There are basically two major forms of assessment in use today: summative and formative. Summative assessment attempts to "summarize" student performance at some point in time, usually in a written test, for example, a final examination at the end of a course. Almost all summative assessments are high stakes in that they are attached to a significant event, such as a grade or a minimal level of achievement for admission to a college or university. Most "standardized" tests are summative in nature. Formative assessment, on the other hand, provides the student with feedback to facilitate their learning without necessarily being attached to a grade or other high stakes event. In formative assessment, professors can adapt, then, their teaching in order to meet student needs. 
Research suggests that formative assessment, while effective, is not used frequently or well in education because marking and grading are overemphasized while giving useful advice is underemphasized. (Black and William, 1998).

Thelwall (2000) provides a convenient taxonomy of summative/formative assessments as noted in the chart below.

Taxonomy of Applications of Online Assessment

\begin{tabular}{|c|c|c|}
\hline Area & Type & Description \\
\hline Summative & Exam & An assessment for grading purposes \\
\hline Formative/ & Grading & An assessment for grading, but also provides feedback intended to direct future \\
\hline Summative & test & studies \\
\hline Formative & $\begin{array}{c}\text { Open } \\
\text { access test }\end{array}$ & $\begin{array}{l}\text { A grading test that doubles as a set of exercises because students are allowed to } \\
\text { practice before sitting at the test }\end{array}$ \\
\hline Formative & Self-test & $\begin{array}{l}\text { An assessment designed to give students feedback on their progress within a } \\
\text { section or unit of study }\end{array}$ \\
\hline Formative & Exercises & A problem set designed to consolidate learning on a unit of study \\
\hline Formative & $\begin{array}{l}\text { Programmed } \\
\text { learning tool }\end{array}$ & $\begin{array}{l}\text { A linear computer-assisted learning (CAL) package based upon question and } \\
\text { answer (Drill and practice) }\end{array}$ \\
\hline Formative & CAL quiz & $\begin{array}{l}\text { A graded exercise integrated into a CAL package, } \\
\text { i.e., a multiple-choice question presented after an informational slide }\end{array}$ \\
\hline Formative & $\begin{array}{l}\text { Adaptive } \\
\text { CAL quiz }\end{array}$ & $\begin{array}{l}\text { A graded exercise in a CAL package used as a test, } \\
\text { but also used to adapt the teaching to the weaknesses of the student }\end{array}$ \\
\hline Formative & Diagnostic test & An assessment of prior learning taken before a unit of study \\
\hline
\end{tabular}

Online assessments or computer-based assessments have been used effectively in higher education since the 80's. There are many ways in which to use these types of assessments, from placement tests given before students begin study, to formative assessment during study, and later summative testing in final exams. Such assessments are not considered to be replacements for, but complimentary to, traditional testing methods.

Interestingly, extensive use of "formative" evaluation is found in mastery learning techniques. Mastery learning is a method of instruction in which the emphasis is on the role of feedback in learning. Each student must "master" a certain level of performance before moving on to the next section. The mastery model is based on Benjamin Bloom's Learning for Mastery (Bloom, 1968, 1974) and later refined by Block (1974). In the mastery learning technique, material is broken down into a set of sub-skills which are organized in a hierarchy of instructional objectives. For each step in the hierarchy, a formative evaluation is developed and performance criterions are specified for mastery of the sub-skill. The learner begins at the lowest level of the hierarchy, is pretested, receives the content, and is post-tested. If the learner is unable to meet the specified performance criterion for mastery, corrective strategies are introduced until mastery is achieved. The learner moves to the next level in the hierarchy once mastery is achieved for a sub-skill. The strategy relies on frequent feedback loops associated with well-defined and appropriately sequenced sub-skills. Although mastery learning can be adapted to episodic material such as history, it is more effective with sequential material such as math, accounting or foreign languages where prior knowledge is essential to success. The chart below provides a set of general examples for basic mastery methodology using a course management system. These examples focus on the steps and features of using online assessment. 
Examples of Basic Mastery Methodology Using a Course Management System (CMS)

\begin{tabular}{|c|c|c|}
\hline $\begin{array}{l}\text { Step } \\
\end{array}$ & CMS & Feature(s) \\
\hline $\begin{array}{l}\text { Give a pretest and present a review of } \\
\text { the material at the beginning of the } \\
\text { semester. This should address essential } \\
\text { facts, skills, and concepts that are } \\
\text { required for success. Make adjustments } \\
\text { to instructional objectives and content } \\
\text { based on the profile of the class. }\end{array}$ & $\begin{array}{l}\text { This is easily accomplished by } \\
\text { developing the pretest in the CMS and } \\
\text { requiring students to take it at the } \\
\text { beginning of the semester. }\end{array}$ & $\begin{array}{l}\text { Due to the automatic scoring feature } \\
\text { available in most CMS's, the professor } \\
\text { will have a complete inventory of the } \\
\text { skills/abilities of the class before the } \\
\text { next class session begins. }\end{array}$ \\
\hline $\begin{array}{l}\text { Introduction: explain objectives, } \\
\text { content, and procedures for each lesson. } \\
\text { Explain how the material is related to } \\
\text { prior knowledge and experience. }\end{array}$ & $\begin{array}{l}\text { Include a summary in the Course } \\
\text { Information/Course Documents } \\
\text { section(s) for reference and review. }\end{array}$ & $\begin{array}{l}\text { Prerequisite material, reviews, learning } \\
\text { "anchors" can be provided through an } \\
\text { array of multimedia experiences. }\end{array}$ \\
\hline $\begin{array}{l}\text { Present the concept or skill by } \\
\text { providing demonstrations and } \\
\text { examples. }\end{array}$ & $\begin{array}{l}\text { These can be included in the "content" } \\
\text { section of the CMS or examples can be } \\
\text { provided that reinforce the material } \\
\text { covered in class. Changes in the focus } \\
\text { or review are made based on results of } \\
\text { the pretest. }\end{array}$ & \\
\hline $\begin{array}{l}\text { Lead the learner through } \\
\text { demonstrations and examples. }\end{array}$ & $\begin{array}{l}\text { Perfect time to use the classroom flip } \\
\text { methodology, where rote lecture } \\
\text { material is moved to the web. }\end{array}$ & $\begin{array}{l}\text { Present reading, demos, examples using } \\
\text { the CMS outside of class. Use class } \\
\text { time to answer questions, guide hands- } \\
\text { on activity, etc. }\end{array}$ \\
\hline $\begin{array}{l}\text { Engage the student in the formative } \\
\text { assessment where his/her work is } \\
\text { monitored, feedback is received, and } \\
\text { performance is assessed for corrective } \\
\text { action or for advancement. }\end{array}$ & $\begin{array}{l}\text { Develop assessments based on a } \\
\text { hierarchy of sub-skills. Set a level of } \\
\text { mastery. Provide remedial activities for } \\
\text { those in need. Provide advanced } \\
\text { materials for high achieving students. }\end{array}$ & $\begin{array}{l}\text { Use of feedback capabilities of the } \\
\text { CMS to guide the student. Automatic } \\
\text { scoring allows the professor to focus on } \\
\text { student progress and needs rather than } \\
\text { just "marking". }\end{array}$ \\
\hline
\end{tabular}

\section{EXAMPLES OF EFFECTIVE PRACTICES IN THE USE OF ONLINE ASSESSMENT}

There are numerous advantages associated with using online assessment tools, such as: professors can assess progress of their students more frequently, students are able to monitor their own progress, feedback can be provided to students immediately, allows for inclusion of multi-media elements which are not possible in paper assessments and statistics or other reports can be generated automatically.

One advantage of using online assessment tools is that computers excel at storing and retrieving data. Using these capabilities, professors are able to assess student progress more frequently, often without giving up valuable class time. Computers relieve the professor of administering, scoring, and recording the results of assessments. This is done automatically. The professor is able to walk into the classroom knowing who has completed a quiz or discussion activity (often an indicator of who has done the reading assignment) and which items were missed by the majority of students. Another advantage on using online assessment tools is that students are able to monitor their own progress. Student self-monitoring is essential to meta-cognition, which enables students to adjust and manage their own learning which is positively correlated with study practices and ultimately achievement. (Paris \& Winograd, 1990)

Providing immediate feedback to students is another advantage. Feedback is information given to the learner about the correctness of their answers. (Frayer \& Kluasmeier, 1971) Immediate feedback is more effective than feedback delivered after a delay (Dempsey, Driscoll, \& Swindell, 1993). In some classes students don't find out how they've done until long after a concept has been taught. If they get graded assignments back 3-4 weeks later, they lose interest (especially in large classes). Immediate feedback enables the learner to monitor their understanding leading students to remedial study or to seek help when errors are identified rather than waiting. An additional benefit of immediate feedback is that it encourages students to keep working on problems that are giving them trouble. Professors using online assessment tools may choose to provide item by item feedback or feedback at the end of the assignment. Using the tools found in most course management systems' assessment managers, 
professors can provide students with feedback not only on whether the answer was correct or not, but why. Online assessment also enables professors to present multiple media as sources for assessment easier than any other format. Students can be presented with sound, video, and animation and the capability to input text all from one format. And lastly, statistics and other reports can be generated automatically. Most course management systems allow statistics to be collected and displayed automatically for both individual users and for the entire class. Again, this is a time saver for the professor. When using online assessment tools, students are able to receive their grade immediately after completing a particular type of assignment.

One of the most common testing options in Course Management System is objective type questions, such as multiple choice questions, matching questions, true-false, multiple response questions, sequencing, and ranking type questions. In these types of items, the answers are chosen from or compared to other items provided. Scoring of such items can be performed easily by the computer as judgment about correctness of the answer does not have to be made since correct answers have been predetermined. Objective type tests are popular and frequently used in higher education settings mainly due to their efficiency, especially for large classes. When using computers to deliver objective tests, students must be familiar and comfortable with the technology and contingency plans must be addressed in the event of computer failure.

Most Course Management Systems have the capability to accept essay type questions; however, they cannot be automatically scored. Why, then would you want to use it? Frequently student handwriting in a "Blue Book" format is almost illegible. Having the student "type out" the essay is a life (and eye) saver for both the student and the professor.

\section{GENERAL SUGGESTIONS FOR USING ONLINE ASSESSMENT}

- Make online testing formative rather than summative and give students a short (3-5 questions) quiz before each class session to assure that they are completing the reading assignment. Go over common errors.

- Consider a mastery approach with subsets of skills to be "mastered" before moving on. Provide plenty of feedback. Or give students occasional online "pop" quizzes to see if they are "getting it". Go over any common problem areas.

In summary, when thinking through the most appropriate type of assessment tool to use, one of the most effective approaches is to determine the learning outcome first and then determine the assessment strategy related to that outcome (Ko and Rossen, 2004). For example, the chart below provides some examples of learning outcomes that are directly linked to various assessment strategies. As noted in the chart, no one type of assessment is likely to be the best way to measure all of your learning outcomes and using more than one type of assessment gives learners a variety of ways to demonstrate their achievement (Simonson, Smaldino, Albright, and Zvacek, 2006).

\begin{tabular}{|l|l|}
\hline \multicolumn{2}{|c|}{ The nature of the learning outcome determines the assessment strategy. } \\
\hline \multicolumn{1}{|c|}{$\begin{array}{c}\text { Examples of General } \\
\text { Learning Outcomes }\end{array}$} & \multicolumn{1}{c|}{$\begin{array}{c}\text { Examples of Corresponding } \\
\text { Assessment Strategies }\end{array}$} \\
\hline Know, remember, recognize, recall, identify & Quiz or test \\
\hline Explain, interpret, reason, respond, relate & Discussion \\
\hline Synthesize, develop, argue, generate & Paper, essay, project \\
\hline Demonstrate, illustrate & Presentation \\
\hline Analyze, solve, recommend, discover & Problem-based activities \\
\hline
\end{tabular}

\section{SELECTING ASSESSMENT TOOLS AND GRADING CRITERIA FOR ONLINE DISCUSSION}

While it would be beneficial if all students participated in the discussions for the sake of learning, the pragmatic consideration is that if participation in online discussion is not tied to grading then students will see it as unimportant and choose not to participate (Harasim, Hiltz, Teles and Turoff, 1995). If numerous online discussions 
are required throughout a course, then one option would be only selecting a few of the completed discussions for grading purposes, even though participation in all discussions is a requirement. Possible elements to consider for assigning grades include: how many postings the student reads, how many responses the student provides and length of student contributions. Although these measures are made easy by the statistics the CMS provides on each student's use of the discussion area, they give a student credit for postings that are little more than, "Good job!" Qualitative measures of the value of the contributions are more insightful, but require more work by the professor and/or by peers who evaluate the postings. One suggestion is to include a culminating experience with more formal, graded writing, for example, a paper or test question that incorporates some of what was learned from the discussion, even a citation of a classmate as an additional resource (Reiss, n.d.). If postings result from group work, then all of normal issues of grading group work apply, such as, will the group receive one grade, will individuals each receive a separate grade or will there be some combination of group and individual grade?

\begin{tabular}{|c|c|c|c|c|c|}
\hline Category & Below Average $=1$ & Average $=2$ & Good $=\mathbf{3}$ & Excellent $=4$ & POINTS \\
\hline $\begin{array}{l}\text { Promptness } \\
\text { and } \\
\text { Initiative }\end{array}$ & $\begin{array}{l}\text { Does not respond to } \\
\text { most postings; rarely } \\
\text { participates freely }\end{array}$ & $\begin{array}{l}\text { Responds to most } \\
\text { postings several } \\
\text { days after initial } \\
\text { discussion; limited } \\
\text { initiative }\end{array}$ & $\begin{array}{l}\text { Responds to most } \\
\text { postings within a } \\
24 \text { hour period; } \\
\text { requires } \\
\text { occasional } \\
\text { prompting to post }\end{array}$ & $\begin{array}{l}\text { Consistently } \\
\text { responds to } \\
\text { postings in less } \\
\text { than } 24 \text { hours; } \\
\text { demonstrates } \\
\text { good self- } \\
\text { initiative }\end{array}$ & \\
\hline $\begin{array}{l}\text { Delivery of } \\
\text { Post }\end{array}$ & $\begin{array}{l}\text { Utilizes poor } \\
\text { spelling and } \\
\text { grammar in most } \\
\text { posts; posts appear } \\
\text { "hasty" }\end{array}$ & $\begin{array}{l}\text { Errors in spelling } \\
\text { and grammar } \\
\text { evidenced in } \\
\text { several posts }\end{array}$ & $\begin{array}{l}\text { Few grammatical } \\
\text { or spelling errors } \\
\text { are noted in posts }\end{array}$ & $\begin{array}{l}\text { Consistently uses } \\
\text { grammatically } \\
\text { correct posts with } \\
\text { rare misspellings }\end{array}$ & \\
\hline $\begin{array}{l}\text { Relevance of } \\
\text { Post }\end{array}$ & $\begin{array}{l}\text { Posts topics which } \\
\text { do not relate to the } \\
\text { discussion content; } \\
\text { makes short or } \\
\text { irrelevant remarks }\end{array}$ & $\begin{array}{l}\text { Occasionally posts } \\
\text { off topic; most } \\
\text { posts are short in } \\
\text { length and offer no } \\
\text { further insight into } \\
\text { the topic }\end{array}$ & $\begin{array}{l}\text { Frequently posts } \\
\text { topics that are } \\
\text { related to } \\
\text { discussion } \\
\text { content; prompts } \\
\text { further discussion } \\
\text { of topic }\end{array}$ & $\begin{array}{l}\text { Consistently } \\
\text { posts topics } \\
\text { related to } \\
\text { discussion topic; } \\
\text { cites additional } \\
\text { references related } \\
\text { to topic }\end{array}$ & \\
\hline $\begin{array}{l}\text { Expression } \\
\text { Within the } \\
\text { Post }\end{array}$ & $\begin{array}{l}\text { Does not express } \\
\text { opinions or ideas } \\
\text { clearly; no } \\
\text { connection to topic }\end{array}$ & $\begin{array}{l}\text { Unclear connection } \\
\text { to topic evidenced } \\
\text { in minimal } \\
\text { expression of } \\
\text { opinions or ideas }\end{array}$ & $\begin{array}{l}\text { Opinions and } \\
\text { ideas are stately } \\
\text { clearly with } \\
\text { occasional lack of } \\
\text { connection to } \\
\text { topic }\end{array}$ & $\begin{array}{l}\text { Expresses } \\
\text { opinions and } \\
\text { ideas in a clear } \\
\text { and concise } \\
\text { manner with } \\
\text { obvious } \\
\text { connection to } \\
\text { topic }\end{array}$ & \\
\hline $\begin{array}{l}\text { Contribution } \\
\text { to } \\
\text { the } \\
\text { Learning } \\
\text { Community }\end{array}$ & $\begin{array}{l}\text { Does not make } \\
\text { effort to participate } \\
\text { in learning } \\
\text { community as it } \\
\text { develops; seems } \\
\text { indifferent }\end{array}$ & $\begin{array}{l}\text { Occasionally makes } \\
\text { meaningful } \\
\text { reflection on } \\
\text { group's efforts; } \\
\text { marginal effort to } \\
\text { become involved } \\
\text { with group }\end{array}$ & $\begin{array}{l}\text { Frequently } \\
\text { attempts to direct } \\
\text { the discussion and } \\
\text { to present } \\
\text { relevant } \\
\text { viewpoints for } \\
\text { consideration by } \\
\text { group; interacts } \\
\text { freely }\end{array}$ & $\begin{array}{l}\text { Aware of needs } \\
\text { of community; } \\
\text { frequently } \\
\text { attempts to } \\
\text { motivate the } \\
\text { group discussion; } \\
\text { presents creative } \\
\text { approaches to } \\
\text { topic }\end{array}$ & \\
\hline \multicolumn{3}{|c|}{ Source: California State University at Hayward: EDUI 6707} & & Total Points & \\
\hline
\end{tabular}


The field of research on threaded discussions has benefited from the development of a number of rubrics and analytical structures to analyze threaded discussions. Johnson, Johnson \& Smith (1998) provide some starting points for using rubrics as an assessment tool. They provide indicators for three- to five-levels of performance that help determine how well goals were accomplished. For example, in assessing whether or not a student used clear reasoning in discussion, these indicators could be used:

\begin{tabular}{|l|l|l|}
\hline \multicolumn{1}{|c|}{ Inadequate } & \multicolumn{1}{c|}{ Middle } & \multicolumn{1}{c|}{ Excellent } \\
\hline $\begin{array}{l}\text { Gives conclusion with no examples or } \\
\text { reasons. }\end{array}$ & $\begin{array}{l}\text { Gives some examples } \\
\text { and reasons for each conclusion. }\end{array}$ & $\begin{array}{l}\text { Consistently gives examples } \\
\text { and reasons for each conclusion. }\end{array}$ \\
\hline
\end{tabular}

An example of a more detailed rubric that can be readily adapted for an online course or web enhanced course is provided below. This rubric focuses on assessing the effectiveness of online discussion activity in the categories of communications: promptness and initiative, delivery of post, relevance of post, expression within the post and contribution to the learning community. This assessment tool also helps faculty evaluate their own involvement and contributions to the discussion (Garrison, Anderson and Archer, 2001).

Another example of a detailed assessment rubric that could be used or modified to evaluate higher order thinking skills as related to online discussion activity appears below. This rubric was developed by the Teaching and Learning Center at Washington State University. This assessment tool can be used to evaluate cricial and integrative thinking associated with the mastery learning methods discussed in the previous section. Similar to the previous assessment rubric, this rubric evaluates different categories of achievement.

\section{Guide to Rating Critical \& Integrative Thinking Washington State University, Fall 2006}

For each of the seven criteria below, assess the work by:

a) circling specific phrases that describe the work, and writing comments

b) circling a numeric score

Note: A score of 4 represents competency for a student graduating from WSU.

\section{Overall Rating}

\begin{tabular}{|l|l|l|}
\hline \multicolumn{1}{|c|}{ Criteria } & Score \\
\hline 1. & Identify problem, question, or issue & \\
\hline 2. & Consider context and assumptions & \\
\hline 3. & Develop own position or hypothesis & \\
\hline 4. & Present and analyze supporting data & \\
\hline 5. & Integrate other perspectives & \\
\hline 6. & Identify conclusions and implications & \\
\hline 7. & Communicate effectively & \\
\hline \multicolumn{2}{|l|}{ Comments: } & \\
\hline
\end{tabular}


1. Identifies, summarizes (and appropriately reformulates) the problem, question, or issue.

Emerging Developing
\begin{tabular}{|c|l|l|l|}
\hline 1 & \multicolumn{1}{|c|}{2} & \multicolumn{1}{c|}{ Mastering } \\
\hline $\begin{array}{l}\text { Does not attempt to or fails to } \\
\text { identify and summarize accurately. }\end{array}$ & $\begin{array}{l}\text { Summarizes issue, though some } \\
\text { aspects are incorrect or confused. } \\
\text { Nuances and key details are missing } \\
\text { or glossed over. }\end{array}$ & $\begin{array}{l}\text { Clearly identifies the challenqe and } \\
\text { subsidiary, embedded, or implicit } \\
\text { aspects of the issue. Identifies } \\
\text { integral relationships essential to } \\
\text { analyzing the issue. }\end{array}$ \\
\hline
\end{tabular}

2. Identifies and considers the influence of context * and assumptions.

\begin{tabular}{|c|c|c|}
\hline Emerging & Developing & Mastering \\
\hline \begin{tabular}{|c|c|}
1 & 2 \\
\end{tabular} & \begin{tabular}{|c|c|}
3 & 4 \\
\end{tabular} & \begin{tabular}{|c|c}
5 & 6 \\
\end{tabular} \\
\hline $\begin{array}{l}\text { Approach to the issue is in eqocentric } \\
\text { or socio-centric terms. Does not relate } \\
\text { issue to other contexts (cultural, } \\
\text { political, historical, etc.). }\end{array}$ & $\begin{array}{l}\text { Presents and explores relevant } \\
\text { contexts and assumptions reqarding } \\
\text { the issue, although in a limited way. }\end{array}$ & $\begin{array}{l}\text { Analyzes the issue with a clear sense } \\
\text { of scope and context, including an } \\
\text { assessment of audience. Considers } \\
\text { other inteqral contexts. }\end{array}$ \\
\hline $\begin{array}{l}\text { Analysis is grounded in absolutes, } \\
\text { with little acknowledgment of own } \\
\text { biases. }\end{array}$ & $\begin{array}{l}\text { Analysis includes some outside } \\
\text { verification, but primarily relies on } \\
\text { established authorities. }\end{array}$ & $\begin{array}{l}\text { Analysis acknowledges complexity and } \\
\text { bias of vantage and values, although } \\
\text { may elect to hold to bias in context. }\end{array}$ \\
\hline $\begin{array}{l}\text { Does not recognize context or surface } \\
\text { assumptions and underlying ethical } \\
\text { implications, or does so superficially. }\end{array}$ & $\begin{array}{l}\text { Provides some recognition of context } \\
\text { and consideration of assumptions and } \\
\text { their implications. }\end{array}$ & $\begin{array}{l}\text { Identifies influence of context and } \\
\text { questions assumptions, addressing } \\
\text { ethical dimensions underlying the } \\
\text { issue. }\end{array}$ \\
\hline
\end{tabular}

Contexts may include:

Cultural/social

Group, national, ethnic behavior/attitude

Educational

Schooling, formal training

Technological

Applied science, engineering

Political

Orqanizational or qovernmental
Scientific

Conceptual, basic science, scientific method

Economic

Trade, business concerns costs

Ethical

Values

Personal Experience

Personal observation, informal character 
3. Develops, presents, and communicates OWN perspective, hypothesis or position.

\begin{tabular}{|c|c|c|}
\hline Emerging & Developing & Mastering \\
\hline \begin{tabular}{|c|c|}
1 & 2 \\
\end{tabular} & \begin{tabular}{|c|c|}
3 & 4 \\
\end{tabular} & \begin{tabular}{|c|c|}
5 & 6 \\
\end{tabular} \\
\hline $\begin{array}{l}\text { Position or hypothesis is clearly } \\
\text { inherited or adopted with little oriqinal } \\
\text { consideration. }\end{array}$ & $\begin{array}{l}\text { Position includes some original } \\
\text { thinkinq that acknowledqes, refutes, } \\
\text { synthesizes or extends other } \\
\text { assertions, although some aspects } \\
\text { may have been adopted. }\end{array}$ & $\begin{array}{l}\text { Position demonstrates ownership for } \\
\text { constructinq knowledqe or framing } \\
\text { original questions, integrating } \\
\text { objective analysis and intuition. }\end{array}$ \\
\hline $\begin{array}{l}\text { Addresses a sinqle source or view of } \\
\text { the arqument, failina to clarify the } \\
\text { established position relative to one's } \\
\text { own. }\end{array}$ & $\begin{array}{l}\text { Presents own position or hypothesis, } \\
\text { though inconsistently. }\end{array}$ & $\begin{array}{l}\text { Appropriately identifies own position } \\
\text { on the issue, drawing support from } \\
\text { experience, and information not } \\
\text { available from assigned sources. }\end{array}$ \\
\hline $\begin{array}{l}\text { Fails to present and justify own } \\
\text { opinion or forward hypothesis. }\end{array}$ & $\begin{array}{l}\text { Presents and justifies own position } \\
\text { without addressing other views, or } \\
\text { does so superficially. }\end{array}$ & $\begin{array}{l}\text { Clearly presents and justifies own } \\
\text { view or hypothesis while qualifying or } \\
\text { inteqrating contrary views or } \\
\text { interpretations. }\end{array}$ \\
\hline $\begin{array}{l}\text { Position or hypothesis is unclear or } \\
\text { simplistic. }\end{array}$ & $\begin{array}{l}\text { Position or hypothesis is qenerally } \\
\text { clear, although gaps may exist. }\end{array}$ & $\begin{array}{l}\text { Position or hypothesis demonstrates } \\
\text { sophisticated, inteqrative thought and } \\
\text { is developed clearly throughout. }\end{array}$ \\
\hline
\end{tabular}

4. Presents, assesses, and analyzes appropriate supporting data/evidence.

\begin{tabular}{|c|c|c|}
\hline Emerging & Developing & Mastering \\
\hline \begin{tabular}{|c|c|}
1 & 2 \\
\end{tabular} & \begin{tabular}{|c|c|}
3 & 4 \\
\end{tabular} & \begin{tabular}{|l|l|}
5 & 6 \\
\end{tabular} \\
\hline $\begin{array}{l}\text { No evidence of search, selection or } \\
\text { source evaluation skills. }\end{array}$ & $\begin{array}{l}\text { Demonstrates adequate skill in } \\
\text { searching, selecting, and evaluating } \\
\text { sources to meet the information need. }\end{array}$ & $\begin{array}{l}\text { Evidence of search, selection, and } \\
\text { source evaluation skills; notable } \\
\text { identification of uniquely salient } \\
\text { resources. }\end{array}$ \\
\hline $\begin{array}{l}\text { Repeats information provided without } \\
\text { question or dismisses evidence } \\
\text { without adequate justification. }\end{array}$ & $\begin{array}{l}\text { Use of evidence is qualified and } \\
\text { selective. }\end{array}$ & $\begin{array}{l}\text { Examines evidence and its source; } \\
\text { questions its accuracy, relevance, and } \\
\text { completeness. }\end{array}$ \\
\hline $\begin{array}{l}\text { Does not distinquish amonq fact, } \\
\text { opinion, and value judgments. }\end{array}$ & $\begin{array}{l}\text { Discerns fact from opinion and may } \\
\text { recoqnize bias in evidence, although } \\
\text { attribution is inappropriate. }\end{array}$ & $\begin{array}{l}\text { Demonstrates understanding of how } \\
\text { facts shape but may not confirm } \\
\text { opinion. Recoanizes bias, includina } \\
\text { selection bias. }\end{array}$ \\
\hline $\begin{array}{l}\text { Conflates cause and correlation; } \\
\text { presents evidence and ideas out of } \\
\text { sequence. }\end{array}$ & $\begin{array}{l}\text { Distinquishes causality from } \\
\text { correlation, though presentation may } \\
\text { be flawed. }\end{array}$ & $\begin{array}{l}\text { Correlations are distinct from causal } \\
\text { relationships between and amona } \\
\text { ideas. Sequence of presentation } \\
\text { reflects clear orqanization of ideas, } \\
\text { subordinating for importance and } \\
\text { impact. }\end{array}$ \\
\hline $\begin{array}{l}\text { Data/evidence or sources are } \\
\text { simplistic, inappropriate, or not } \\
\text { related to topic. }\end{array}$ & $\begin{array}{l}\text { Appropriate data/evidence or sources } \\
\text { provided, although exploration } \\
\text { appears to have been routine. }\end{array}$ & $\begin{array}{l}\text { Information need is clearly defined } \\
\text { and inteqrated to meet and exceed } \\
\text { assianment, course or personal } \\
\text { interests. }\end{array}$ \\
\hline
\end{tabular}




\section{Integrates issue using $\underline{O T H E R}$ (disciplinary) perspectives and positions.}

Emerging

\begin{tabular}{|c|c|c|}
\hline LWHerg & & \\
\hline 1 & \begin{tabular}{|l|l}
3 & 4 \\
\end{tabular} & \begin{tabular}{|l|l}
5 & 6 \\
\end{tabular} \\
\hline $\begin{array}{l}\text { Deals with a single perspective and } \\
\text { fails to discuss others' perspectives. }\end{array}$ & $\begin{array}{l}\text { Begins to relate alternative views to } \\
\text { qualify analysis. }\end{array}$ & $\begin{array}{l}\text { Addresses others' perspectives and } \\
\text { additional diverse perspectives drawn } \\
\text { from outside information to qualify } \\
\text { analysis. }\end{array}$ \\
\hline $\begin{array}{l}\text { Adopts a single idea or limited ideas } \\
\text { with little question. If more than one } \\
\text { idea is presented, altematives are not } \\
\text { inteqrated. }\end{array}$ & $\begin{array}{l}\text { Rough integration of multiple } \\
\text { viewpoints and comparison of ideas or } \\
\text { perspectives. Ideas are investigated } \\
\text { and integrated, but in a limited way. }\end{array}$ & $\begin{array}{l}\text { Fully integrated perspectives from } \\
\text { variety of sources; any analogies are } \\
\text { used effectively. }\end{array}$ \\
\hline $\begin{array}{l}\text { Enqaqes ideas that are obvious or } \\
\text { agreeable. Avoids challenging or } \\
\text { discomforting ideas. }\end{array}$ & $\begin{array}{l}\text { Enqaqes challenqing ideas tentatively } \\
\text { or in ways that overstate the conflict. } \\
\text { May dismiss alternative views hastily. }\end{array}$ & $\begin{array}{l}\text { Inteqrates own and others' ideas in a } \\
\text { complex process of judgment and } \\
\text { justification. Clearly justifies own view } \\
\text { while respecting views of others. }\end{array}$ \\
\hline $\begin{array}{l}\text { Treats other positions superficially or } \\
\text { misrepresents them. }\end{array}$ & $\begin{array}{l}\text { Acknowledges and integrates different } \\
\text { thoughtful and mostly accurate. }\end{array}$ & $\begin{array}{l}\text { Analysis of other positions is accurate, } \\
\text { nuanced, and respectful. }\end{array}$ \\
\hline $\begin{array}{l}\text { Little inteqration of perspectives and } \\
\text { little or no evidence of attendina to } \\
\text { others' views. No evidence of } \\
\text { reflection or self-assessment. }\end{array}$ & $\begin{array}{l}\text { ways of knowina. Some evidence of } \\
\text { reflection and/or self-assessment. }\end{array}$ & $\begin{array}{l}\text { Inteqrates different disciplinary and } \\
\text { epistemoloqical ways of knowing. } \\
\text { Connects to career and civic } \\
\text { responsibilities. Evidence of reflection } \\
\text { and self-assessment. }\end{array}$ \\
\hline
\end{tabular}

6. Identifies and assesses conclusions, implications, and consequences.

Emerging

Developing

Fails to identify conclusions,

implications, and consequences, or

conclusion is a simplistic summary.

Conclusions consider or provide evidence of consequences extending bevond a sinqle discipline or issue. Presents implications that may impact other people or issues.

Conclusions presented as absolute, and may attribute conclusion to external authority.
Presents conclusions as relative and only loosely related to consequences. Implications may include vague reference to conclusions.
Mastering

\begin{tabular}{|l|c|}
\multicolumn{1}{|c|}{5} & \multicolumn{1}{c}{ Mastering } \\
\hline
\end{tabular}

\section{Communicates effectively.}

\begin{tabular}{|c|c|c|}
\hline Emerging & Developing & Mastering \\
\hline \begin{tabular}{|c|c|}
1 & 2 \\
\end{tabular} & \begin{tabular}{|c|r|}
3 & 4 \\
\end{tabular} & \begin{tabular}{|c|c|}
5 & 6 \\
\end{tabular} \\
\hline $\begin{array}{l}\text { In many places, language obscures } \\
\text { meaning. }\end{array}$ & $\begin{array}{l}\text { In general, language does not } \\
\text { interfere with communication. }\end{array}$ & $\begin{array}{l}\text { Language clearly and effectively } \\
\text { communicates ideas. May at times be } \\
\text { nuanced and eloquent. }\end{array}$ \\
\hline $\begin{array}{l}\text { Grammar, syntax, or other errors are } \\
\text { distracting or repeated. Little } \\
\text { evidence of proofreading. Style is } \\
\text { inconsistent or inappropriate. }\end{array}$ & $\begin{array}{l}\text { Errors are not distracting or frequent, } \\
\text { although there may be some } \\
\text { problems with more difficult aspects } \\
\text { of style and voice. }\end{array}$ & $\begin{array}{l}\text { Errors are minimal. Style is } \\
\text { appropriate for audience. }\end{array}$ \\
\hline $\begin{array}{l}\text { Work is unfocused and poorly } \\
\text { orqanized; lacks loqical connection of } \\
\text { ideas. Format is absent, inconsistent } \\
\text { or distracting. }\end{array}$ & $\begin{array}{l}\text { Basic orqanization is apparent; } \\
\text { transitions connect ideas, althouqh } \\
\text { they may be mechanical. Format is } \\
\text { appropriate althouqh at times } \\
\text { inconsistent. }\end{array}$ & $\begin{array}{l}\text { Orqanization is clear; transitions } \\
\text { between ideas enhance presentation. } \\
\text { Consistent use of appropriate format. } \\
\text { Few problems with other components } \\
\text { of presentation. }\end{array}$ \\
\hline $\begin{array}{l}\text { Few sources are cited or used } \\
\text { correctly. }\end{array}$ & $\begin{array}{l}\text { Most sources are cited and used } \\
\text { correctly. }\end{array}$ & $\begin{array}{l}\text { All sources are cited and used } \\
\text { correctly, demonstratina } \\
\text { understanding of economic, legal and } \\
\text { social issues involved with the use of } \\
\text { information. }\end{array}$ \\
\hline
\end{tabular}


As previously noted, there are several types of assessment tools that can be used to evaluate online discussion activity. Several research studies suggest that using an assessment rubric similar the ones presented above can be beneficial in structuring the assessment of an online discussion to be more objective and consistent (Garrison, Anderson and Archer, 2001; Edelstein and Edwards, 2002). They also emphasized that this type of assessment tool provides students with guidelines for how their work will be assessed according to the professor's expectations. These studies conclude that "actual implementation of a rubric for assessment will largely depend upon the professor's preference for objective feedback and whether or not, he or she would prefer weekly assessment or summative and formative feedback as the course progresses" (Edelstein and Edwards, 2002).

\section{CONCLUSIONS}

As noted in the previous sections, the larger number of students enrolled in a particular course, the more time it takes to integrate discussion activity effectively. Research studies suggest that grouping individuals in pairs or teams can reduce the time involved in discussion activity and thus, increase the quality of time devoted to discussions that are directly linked to specific learning outcomes. Therefore, the concept of collaborative learning, the grouping and pairing of students for the purpose of achieving a common goal, has been an accepted instructional strategy for use with discussion activities, either in-class or online.

Proponents of collaborative learning indicate that active exchange of ideas within small groups not only increases interest among students but also promotes critical thinking in which students achieve higher levels of thought and retain information longer than students who work on their own in an independent manner (Johnson and Johnson, 1986). Therefore, using discussion activity that focuses on the devleopment of critical thinking through discussion, clarification of ideas, explanation of concepts to others, and evaluation of other's ideas can enhance collaborative learning processes. For example, a good starter discussion activity is to assign pairs of students to research a question or problem and report their results to the entire group. A further step is to ask teams to evaluate each other's work. Alternatively, a team can be composed of three individuals, one of whom is charged with proposing an initial answer, the second provides a alternative answer, and the third provides a critique or synthesis of the first two responses (Slavin, 1989).

Also noted in the previous sections was the importance of clearly defining the learning outcome for which the discussion activity is designed to achieve and selecting the appropriate assessment tool to evalutate the effectiveness of working toward achieving the specific outcome. This study recommends using assessment rubrics that focus on evalutating the qualitative aspects of discussion activity as a prefered method of assessment if the goal is to enhance higher order thinking skills. This study concludes that using best practices in both online discussions and online assessments can enhance collaborative learning processes, which results in students having a deeper understanding of course content, higher motivation to remain engaged on task, improved teamwork and interpersonal skills, enhanced critical thinking abilities, improved self-esteem and increased ownership of their own learning.

\section{AUTHOR INFORMATION}

Dr. Debra L. Fleming, CPA, is professor of accounting and management and Executive Director of Undergraduate and Graduate Business Programs at Ursuline College. Dr. Fleming has over ten years of administrative experience in higher education which includes having served as Dean of the School of Business at Dowling College, Associate Vice President for Academic Affairs and Vice President of Learning, Assessment and Technology at Centenary College, and as Assistant Provost for Institutional Effectiveness and Research at Palm Beach Atlantic University. She also served as an accounting professor for thirteen years at Ohio Dominican University and as an adjunct professor for seven years at Ohio State University. She has over twenty two years of teaching experience as a business professor and ten years of experience as a national consultant on technology. 


\section{REFERENCES}

1. Beaudoin M. (2002). Learning or Lurking? Tracking the invisible online student, The Internet and Higher Education, 5, pp. 147-155.

2. Berge, Z. (1997). Computer conferencing and the on-line classroom. International Journal of Educational Telecommunications, 3 (1), pp. 3-21.

Black, P. \& William, D. (1998). Assessment and Classroom Learning. Assessment in Education, March, pp. 7-74.

3. Bloom, B. S. (1956). Taxonomy of educational objectives, handbook 1: Cognitive domain. New York: Longmans Green.

4. Bloom, B. S. (1968/70). Learning for Mastery. (UCLA-CSEIP) The Evaluation Comment, 1 (2), Reprinted in Block, J.H. (Ed.) Mastery Learning, New York: Holt Rinehart and Wilson, pp. 47-63.

5. Bredo, E. (2000). Reconsidering Social Constructivism: The Relevance of George Herbert Mead's Interactionism. Chapter 5. In Phillips, D.C. (ed.) (2000) Constructivism in Education: Opinions and Second Opinions on controversial issues: $99^{\text {th }}$ Yearbook of the National Society for the Study of education. Part 1. Chicago, Illinois. The University of Chicago Press.

6. Brown, I. (1991). To learn is To Teach is To Create the Final Exam. College Teaching, 39 (4), pp. 150-153. Bruner, J. (1985). Vygotsky: An historical and conceptual perspective. Culture, communication, and cognition: Vygotskian perspectives, London: Cambridge University Press. pp. 21-34.

7. Cashin, W. E. \& McKnight, P. C. (1989). "Improving discussions.” In R. A. Neff \& M. Weimer (Eds.), Classroom communication: Collected readings for effective discussion and questioning (pp. 33-40). Madison, WI: Magna Publications, Inc.

8. Chickering, A., \& Ehrmann, S.C. (1996). Implementing the seven principles: Technology as a lever. AAHE Bulletin, October, 49(2), pp. 3-6.

9. Cummings, J. A. (1998). Promoting Student Interaction in the Virtual College Classroom. Available http://www.ihets.org/learntech/distance_ed/fdpapers/1998/52.html. (22 para.) Accessed May 9, 2007.

10. Curtis, D. D., and Lawson, M. J. (2001). “Exploring Collaborative Online Learning.” Journal of Asynchronous Learning Networks, Vol. 5, No. 1, pp 21-34, 2001.

11. Dempsey, J., Driscoll, M., \& Swindell, L. (1993). Text-based feedback. in Dempsey, J. and Sales, G., Interactive Instruction and Feedback, NJ: Educational Technology Publications. pp. 21-54.

12. Dochy, F. \& McDowell, Liz (1997). Assessment as a Tool for Learning. Studies in Educational Evaluation, 23, (4), pp. 279-298.

13. Edelstein, S. and Edwards, J. (2002). If You Build It, They Will Come: Building Learning Communities Through Threaded Discussions. Online Journal of Distance Learning Administration, Volume V, Number I, Spring.

14. $\quad$ Ewens, W. (1989). “Teaching using discussion.” In R. A. Neff \& M. Weimer (Eds.), Classroom communication: Collected readings for effective discussion and questioning (pp. 27-30). Madison, WI: Magna Publications, Inc.

15. Frederick, P. (1989). “The dreaded discussion: Ten ways to start.” In R. A. Neff \& M. Weimer (Eds.), Classroom communication: Collected readings for effective discussion and questioning (pp. 9-18). Madison, WI: Magna Publications, Inc.

16. Garrison, D. R., Anderson, T., and Archer, W. (2001). "Critical Thinking, Cognitive Presence, and Computer Conferencing in Distance Education.” The American Journal of Distance Education, Vol. 15, No. 1, pp. 7-23.

17. Goodwin, S. (1989). "Planning questions." In R. A. Neff \& M. Weimer (Eds.), Classroom communication: Collected readings for effective discussion and questioning (pp. 91-92). Madison, WI: Magna Publications, Inc.

18. Harasim, L., Hiltz, S. R., Teles, L. \& Turoff, M. (1995). Learning networks: A field guide to teaching and learning online. Cambridge, MA: The MIT Press.

19. Hirumi, A., \& Bermudez, A. (1996). "Interactivity, distance education, and instructional systems design converge on the information superhighway." Journal of Research on Computing in Education, 29(1), pp. $1-16$. 
20. Horn, D. (1994). “Distance education: Is interactivity compromised?" Performance and Instruction, 33(9), pp. 12-15.

21. Johnson, D. W., Johnson, R. T., \& Smith, K. A. (1998). Active learning: Cooperation in the college classroom. Edina, MN: Interaction Book Company.

22. Johnson, R. T., \& Johnson, D. W. (1986). Action research: Cooperative learning in the science classroom. Science and Children, 24, pp. 31-32.

23. Ko, S., and Rossen, S. (2004). Teaching online: A practical guide ( $2^{\text {nd }}$ Ed.). Boston: Houghton Mifflin.

24. Kollock, P. and Smith, M. (1996). Managing the virtual commons: cooperation and conflict in computer communities. Proceedings of Computer-Mediated Communication: Linguistic, Social, and Cross-Cultural Perspective Conference. Amsterdam. pp. 109-128.

25. Kurfiss, Joanne. (1988). Critical Thinking: Theory, Research, Practice, and Possibilities. ASHE-ERIC Higher Education Report No. 2. Washington D.C.: Association for the Study of Higher Education.

26. Maslow, A.H. (1972). Defence and Growth (pp.43-51). In Silberman, M.L. (ed) The Psychology of Open Teaching and Learning. Boston. Little Brown.

27. Neff, R. A. \& Weimer, M. (1989). Classroom communication: Collected readings for effective discussion and questioning. Madison, WI: Magna Publications, Inc.

28. Newman, D. R., Webb, B., and Cochrane, C. (1999). "A Content Analysis Method to Measure Critical Thinking" in Face-to-Face and Computer Supported Group Learning, 1999. Accessed March 3, 2008 http://www.qub.ac.uk/mgt/papers/methods/contpap.html.

29. Nonnecke, B. and Preece, J. (2000). Silent Participants: Getting to Know Lurkers Better? Chapter 6. pp. 110-132. In. From Usenet to CoWebs. Available online: http://www.cis.uoguelph.ca/ nonnecke/research/silentparticipants.pdf. Accessed September 04, 2007.

30. Paris, S. \& Winograd, P. (1990). How Meta-cognition Can Promote Academic Learning and Instruction, in Dimensions of Thinking and Cognitive Instruction, Jones, B. \& Idol, L. (Eds.) Hillsdale, NJ: Earlbaum, pp. $15-52$

31. Reiss, D. (n.d.). Tips for Interactive Online Learning. (List of 11 points) Available http://waltoncollege.uark.edu/disted/tips for_interactive_online_lear.htm. Accessed May 20, 2007.

32. Salmon, G. (2000). E-Moderating: The Key to Teaching and Learning Online. London. Kogan.

33. Shapley, P. (2000). "On-line Education to Develop Complex Reasoning Skills in Organic Chemistry." Journal of Asynchronous Learning Networks, Vol. 4, No. 2.

34. Sherry, L. (1998). The Nature and Purpose of Online Discourse: A Brief Synthesis of Current Research as related to The WEB Project. Article submitted for publication in the International Journal of Educational Telecommunications. Available http://www.cudenver.edu/ lsherry/pubs/dialogue.htm. Accessed May 9, 2006.

35. Shneiderman, B. (1994). Education by Engagement and Construction: Can Distance Education be Better than Face-to-Face? http://www.hitl.washington.edu/scivw/EVE/distance.html. Accessed May 20, 2007.

36. Simonson, M., Smaldino, S., Albright, M., and Zvacek, S. (2006). Teaching and learning at a distance: Foundations of distance education ( $3^{\text {rd }}$ Ed.). Upper Saddle River, NJ: Pearson.

37. Slavin, R. E. (1989). Research on cooperative learning: An international perspective. Scandinavian Journal of Educational Research, 33(4), pp. 231-243.

38. The Critical Thinking Rubric. Washington State University, http://wsuctproject.wsu.edu/ctr.htm, Accessed May 21, 2008.

39. Thelwall, M. (2000). Computer-based assessment: a versatile educational tool. Computers and Education, 34, pp. 37-49.

40. Totten, S., Sills, T., Digby, A., \& Russ, P. (1991). Cooperative learning: A guide to research. New York: Garland.

41. Webb, N. (1985). Student interaction and learning in small groups: A research summary. Learning to Cooperate, Cooperating to Learn, pp. 148-172.

42. Weimer, M. (1989). "Research summary: Professors part of the problem?" In R. A. Neff \& M. Weimer (Eds.), Classroom communication: Collected readings for effective discussion and questioning (pp. 69-71). Madison, WI: Magna Publications, Inc.

43. Vygotsky, L. (1978). Mind in society: The development of higher psychological processes. Cambridge: Harvard University Press. 


\section{NOTES}

